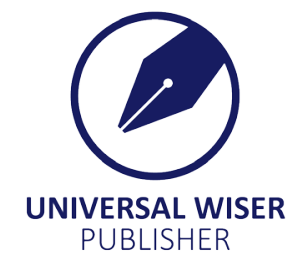

\title{
Managing Projects Using Forensic Accounting in Detection and Prevention of Fraud in Ghana
}

\author{
David Doe Fiergbor \\ KBF Centre for International Studies, Ghana, P. O. Box GS 6040, Accra, Ghana \\ Email: daviddoef@gmail.com
}

\begin{abstract}
Managing projects has become an integral part of business growth and sustainability in contemporary business management practices. As businesses grow and expand, there is a need for prudent and proper management of projects to ensure value for money. Accounting in general has been very critical to the survivor of every business. The complexity of some projects would require more than just average accounting knowledge to ensure their successful planning, execution and completion. It was against this background that this study sought to evaluate "managing projects using forensic accounting in detection and prevention of fraud". The study adopted a qualitative approach and Klynveld Peat Marwick Goerdeler (KPMG) Ghana, a renowned international audit firm was purposely sampled for the study due to its broad business engagements in forensic accounting. The study revealed forensic accounting as a relevant tool in the prevention and detection of fraud in project management practices. There were potential red flags of fraud in Ghanaian projects. Forensic accounting would help complete projects according to schedule and boost the credibility of project managers to the general public. The fraud was a general phenomenon that existed in almost every project. The findings also revealed that irrespective of the nature of fraud, forensic accounting could control it. It was concluded that forensic accounting is of enormous essence to the Projects Community in Ghana especially when forensic accountants were retained for forensic accounting purposes.
\end{abstract}

Keywords: forensic accounting, project management, fraud

\section{Introduction}

Previous business scandals took the industry by surprise not merely due to the magnitude of the loss, however additionally due to the invention that dubious accounting practices were largely deceptive and extensive than earlier projected" $^{,[1]}$. All projects could be exposed to the risk of fraud. Generally, big frauds would cripple the whole project resulting in great economic losses to financiers. This would lead to legal tussle which might negatively affect some prominent personalities and loss of good faith in project managers. Exposed dubious conduct by prominent directors had adversely wedged the names, makes, and images of several businesses involved in project management.

Forensic or investigative accounting is considered as the use of economic expertise and analytical outlook carried out in an evidential framework to settle inexplicit business concerns ${ }^{[2]}$. Forensic accounting is therefore a crucial skillset for combating fraudulent activities that may arise in executing projects and ensuring finishing. Forensic accounting also known as forensic auditing was used to investigate financial records to detect fraud, corruption, or misappropriation of assets. Generally this particular type of auditing only occurred in a company after they have detected that fraudulent behavior existed within their organization. Forensic accounting presents fiscal investigation that could be presented at the law court as a foundation for deliberations, consideration and finally conflict resolution.

Project executions are always deemed big business especially in the public domain as there were deep-rooted incidences of fraudulent activities ${ }^{[3]}$. Several fraudulent project management scandals have been discovered in both the public and private sectors in Ghana. Issues of sole contract sourcing, procurement breaches and shady project executions are among the canker of fraudulent activities in Ghanaian projects. These have necessitated the need to implore forensic accounting roles in warding off these fraudulent activities in project management practices as it deepens credibility in business operations. Forensic accounting was deemed a tool for a universal confrontation to curtail criminal activities against social vices such as terrorism financing and money laundering that have hampered national developments ${ }^{[4]}$. Today applications of forensic accounting permeate not just the financial sector but also to other sectors such as in project

Copyright (C2020, David Doe Fiergbor.

DOI: https://doi.org/10.37256/ges.122020343

This is an open-access article distributed under a CC BY license

(Creative Commons Attribution 4.0 International License)

https://creativecommons.org/licenses/by/4.0/ 
management with the intention of fraud detection and prevention.

\section{Literature review}

A project is momentary accountability rendered to produce a special service, product or result. Organizations engage in projects at all operational levels. The number of skilled professionals employed on a particular project depends on the size and complexity of the project to be executed. A project may include developing a new product, service or result, effecting a change in the structure, processes, staffing, or style of an organization, developing or acquiring a new or modified information system, conducting research, constructing a building, industrial plant or infrastructure or implementing, improving or enhancing existing business processes and procedures. The result of a project can create; a product that can either be a component of another item, an enhancement of an item, or an end item in itself; a service or a capability to perform a service; an improvement in the existing product or service lines or a result such as an outcome or a document. Managing a project generally includes; characteristic requirements; addressing the assorted desires, concerns, and expectations of the stakeholders in designing, and the death penalty the project; fixing, maintaining and ending communications among stakeholders that area unit active, effective and cooperative; managing stakeholders towards meeting project needs and making project deliverables. Project management also involves managing the competing project constraints, such as project scope, quality, schedule, budget, resources, and risk.

There have been a series of revolutions in contemporary business environments. Modern applications of technology have affected business drives and operations and ways that were not previously considered feasible. Accounting has played a significant role in the drive for business sustainability and success. Accounting has been a measuring yardstick for business profitability and viability ${ }^{[5]}$. Accounting could be seen as the chain of activities or operations that used to classify, quantify and relay fiscal information to enhance cognizant decision making by the users of such data. It is a means of furnishing users with numerical evidence that is economical for informed decision making ${ }^{[6]}$.

Meyer vs Sefton in 1817 was the first instance when an accountant was used in the court of law as expert witness. It was the precedence for forensic accounting practice which was developed in later years ${ }^{[7]}$. Forensic accounting is the use of accounting and auditing, financial and investigative skills, to settle economic issues within the context of legal proof $f^{[8]}$. Forensic accounting is intended to uncover and reconcile gaps and discrepancies in a firm's financial records. The findings of forensic accounting could be used as shreds of evidence at the court of law. A forensic audit involves rigorous examination and analysis of a business's internal control systems to investigate the possibility of any fraudulent activity typically in cases of suspected asset-theft. Ozkul and Pamukc ${ }^{[9]}$ argued that forensic accounting was a basis for dispute resolution in the court of law. Alpha ${ }^{[10]}$, opined that forensic accounting is a blend of forensic science and accounting. Forensic accounting methodologies would help uncover dubious activities perpetrated in the business as it uses a scientific approach to deduce, summarize and present complex monetary issues to arrive at deductive conclusions in litigations.

Due to the increase in fraudulent practices, there had been an increase in investigative accounting skills to detect and prevent con activities in businesses as agreed by some scholars ${ }^{[11-12]}$. However, such assertions depends on the definition of fraud. It is open knowledge that fraud is intentional misrepresentation of material facts or evidences ${ }^{[13]}$. The cost of implementing procedures to monitor and restrict the fraudulent acts was far less than the fraud risk that companies face each day ${ }^{[14]}$. Forensic audits were mainly used wherever legal practitioners need trusted information a suspected financial crime and when frauds and embezzlement were suspected within an institution. The application of forensic audit would either be "reactive or proactive"

Proactive Forensics: This audit helped businessmen to ensure that their processes stay robust. Its application could be considered from several points of view ${ }^{[15]}$. Proactive investigation or audit involves several phases which include;

Statutory Audit: In this case, auditing principles implore internal controls to be perused and analyzed internal control systems to ensure the protection of corporate assets as well as ensuring regulatory compliance $e^{[16]}$.

Regulatory Compliance: This technique was usually used by government departments or agencies to ensure compliance with government credit policies. It could also be used in government programs ${ }^{[15]}$.

Diagnostic Tool: Forensic accounting techniques could also be used to investigate reviews and operations to ascertain risk emanating from unnoticed sources to initiate focused reviews on particular areas and target specific threats to the organization $^{[16]}$

Investigation of Allegation: The skills of forensic examination were suitable in this case, in the sense that various complaints and allegations could be used as a guild for gathering evidence used in an investigation. This was mentioned as being proactive since such a system is important to the detection and prevention of fraud ${ }^{[1]}$.

Reactive Forensic: The import of this examination was to ascertain the certainty of suspicions of fraud. If a suspect 
is found liable, shreds of evidence are presented in formats that are accepted to a disciplinary committee or a competent law $\operatorname{courr}^{[1]}$. Chatterji ${ }^{[1]}$ opined that due to the processes involved in reactive forensic audit, it was important therefore to understand the following; professional relationship with the auditing firm; authorization and regulation of the scope of the audit; safekeeping of all material facts; confidentiality evidential documents; analysis to the evidence to determine its suitability for legal proceedings and reporting findings in a legally accepted format.

Forensic accountants usually provide answers to questions like where, how did a task occur, where did it occur, what transpired, why that particular task and who was responsible for such task within the project framework. They discharge their duties with suspicious mindsets to dig out fraudulent activities that occurred within the project execution ${ }^{[3]}$. Forensic accountants present financial data or records in an acceptable and comprehensible format as members of the project team. They play major roles in project management as they apply their array of expertise from a wide background to ensure the success of the project. Their operational duties encompass on the following;

- Mounting electronic software or applications to help within the examination and management of economic proof

- Presenting their proof in the form of reports, documents, and manuals

- Aiding in lawful actions, as well as appearing in a law court as associate degree witness. Where necessary making ready photographic documents to buttress their trial proof

\section{Types of fraud that could occur in projects}

Different forms of fraudulent activities which included: organizational fraud, employee misappropriation, merchant scam, venture tricks, consumer scam, procurement fraud, miscellaneous fraud was categorized into three (3) broad headings as internal fraud, external fraud and corruption or collusion ${ }^{[17]}$. Ozilil ${ }^{[18]}$ specific frauds occur in specific industries and fraud schemes vary in scope and context.

Internal Fraud: This was the most common form of fraud found in organizations. The perpetrators of this kind of fraud were managers (i.e. top or middle management) and employees.

External Fraud: This was another form of fraud that was being perpetrated by those outside the organization, which may include customers or organized criminal gangs.

Corruption or Collusion: This was one of the most difficult kinds of fraud to recognize. It was a fraud perpetrated within the corporation by an inside employee and an outsider.

Forensic auditing strengthened control mechanisms, to protect the businesses and projects against potentially harmful frauds that could cripple their viability and survival. Forensic accounting ensures businesses' compliance with statutory regulatory policies. Businesses secure their reputations and brands when not caught up in any fraudulent activities. This enables businesses to have a completive brand name in their operational sectors. Forensic accounting provides verifiable shreds of evidence that could be used for dispute resolution at the law court. It also helps businesses improve upon their service delivery and customer satisfaction ratings as areas of wastage are identified and blocked. Forensic ensure transparency in business operations and possible loopholes of conflicts of interests are identified and managed.

The nature and scope of forensic audits are such that if not well managed, it could defeat its purpose. It might become cumbersome and chomp undue management time. This will result in unplanned schedule delays that would slack the project. When the scope of the audit is redefined, it would be likely to affect the budget and attract additional costs. Also, some executive members are likely to perceive forensic accounting or audit as a smudge on their personality instead of a proactive mechanism to the advantage of the project.

\section{How an audit firm qualifies to conduct forensic accounting}

Forensic firms investigate the likelihood of illegal business transactions with the project. Their scope of operation encompasses a wide variety of fraud and fraudulent activities and associated crimes. To some KPMG staff who are experience with forensic accounting, an accounting firm qualifies to conduct a forensic audit by gaining forensic accreditation from an organization that is recognized in conducting a forensic audit. There will be a forensic audit department that does a forensic audit and other services. To these staff of KPMG, they will recommend the forensic audit department to every accounting firm working on projects because; the department increases revenue for the firm as there is a market for it and it gives employment to students who are trained as forensic auditors who will add knowledge to the firm.

\subsection{Knowledge and skills of forensic accountants}

The dynamic nature of the global economy precast the profession of forensic accounting ${ }^{[19]}$. Traditional and forensic 
accountants though may have varying scopes of work, they have similar professional skill requirements and expertise. Traditional accounting is usually carried out to report financial information to the users of such information. A forensic audit is rather carried out with a suspicious mindset to identify and prevent fraud in business operations or projects. The work of forensic audit borders areas such as lost profits as a result of pilfering and employee embezzlement as well as litigation services amongst others ${ }^{[20]}$. KPMG staff stated that the knowledge, skills, and abilities needed by a professional auditor to become a forensic auditor are; communication, methodical, presentation, team player, creative thinking and logical reasoning among others. Higson ${ }^{[21]}$ opined that a forensic team should possess robust knowledge in economic fraud, relevant experience, research background, team work spirit and ability to attest and provide necessary evidence in the court of law.

\subsection{Retainment of forensic accountants on project management teams}

Forensic auditors are toughened examiners, auditors, and investigators of financial and legal expertise to uncover and ascertain suspicious fraudulent activities. According to these staff of KPMG, organizations like law firms, project management corporations, banks, government agencies, insurance companies, and other organizations should retain forensic accountants. The researcher opined that forensic accountants' area unit preserved to research, interpret, summarize and gift advanced monetary and business-related problems merely and shortly. The staff of KPMG again opined that to reduce or eliminate fraud within a project before external auditors uncover them, project managers should consider retaining a forensic accountant. Forensic auditors or accountants will facilitate to investigate, interpret, summarize and gift advanced monetary and business-related problems merely and briefly.

\subsection{Types of frauds in project management}

Different types of fraud may occur during project execution which may include procurement breaches and budget inflation among others. However, Omane-Antwi ${ }^{[22]}$ also identified the following as the most common types of fraud;

Table 1. Misappropriation of assets

\begin{tabular}{cc}
\hline Account & Schemes \\
\hline Cash & Fraudulent disbursements, Larceny, Kitting, Skimming, Forgery, Phony refunds \\
Sales / Account Receivables & Fictitious write-offs and Lapping \\
Purchasing / Inventory & Misdirected shipments, nonexistence vendor, theft, duplicate payments, kickbacks, etc. \\
Fixed Assets & Unofficial private use of properties, fabricated theft. \\
Payroll & Ghost employees (ghost names), counterfeit time cards. \\
\hline
\end{tabular}

Source: Felix I. Lessambo ${ }^{[23]}$

Table 2. Fraudulent financial reporting

\begin{tabular}{cc}
\hline Fictitious Revenues & $\begin{array}{c}\text { Recordings of sales of goods or services that never occurred timing differences, recognizing } \\
\text { revenue in improper periods. }\end{array}$ \\
\hline $\begin{array}{c}\text { Assets overstatement } \\
\text { Unrecorded Liabilities and Expenses } \\
\text { Improper Disclosures }\end{array}$ & $\begin{array}{c}\text { Recording certain assets at market values than the lower cost. } \\
\text { Not recording an environmental contingency that is probable and reasonably estimable. } \\
\text { Not disclosing related party transactions or other significant events. }\end{array}$ \\
\hline
\end{tabular}

Source: Omane-Antwi K. Bosiako ${ }^{[22]}$

Table 3. Corruption

$\frac{\text { Table 3. Corruption }}{\text { Areas of concern are; economic extortion, illegal gratuities, bribery and conflicts of interest. }}$

\subsection{Using forensic accounting to reduce fraud to the minimum in projects}

The issues of fraud cases in project executions in Ghana constantly show that there were indications of fraud but either much attention was not paid to them or they were just ignored. There should be someone responsible to act upon every suspicious concern of fraud. According to these staff of KPMG, these red flags can be prevented by; Risk assessment, Awareness and training and Due diligence on staff and business partners. To the author, project team members must be aware that fraud is ongoing at any time. To create this awareness, training must be given to team members to be aware of fraud occurrences and its consequences to the team and the project as a whole. This means that engaging fraud preventive measures only ensure risk management measures of fraud and not guaranteed that fraud would not occur. Awareness of 
fraud ought to be promoted from all levels of the project management teams to ensuring its avoidance or mitigating the risk of its occurrences.

\subsection{Fraud as a general phenomenon which exists almost in every project}

Everyone is aware of stories of fraud. They usually seem within the media and are followed with avid curiosity. People seem to need to understand why fraud happens and why someone imagined they would get away with it especially in projects. Perpetrators of fraud area unit usually standard, well-like people that others trust and respect. But the question is, is fraud a general phenomenon in all projects? According to these KPMG staff, fraud is a general phenomenon in almost every project. This means that all projects are potentially at risk of fraud which can do considerable damage to the project. Big frauds often lead to the total collapse of the project, loss of investor confidence and some cases legal suit against project management or business executives.

\subsection{Forensic accounting in prevention and detection of fraud in projects}

To these staff at KPMG, forensic accounting is a useful mechanism for the prevention and detection of fraud in a project. It now becomes imperative for forensic accounting to become an integral component of project management practices. This would help to combat the occurrence of fraud in projects perpetrated by individuals or as organized crime. According to KPMG, forensic accounting as a preventive and detective tool of fraud will help minimize fraud in projects as a whole.

\subsection{Challenges of the forensic accounting}

To these KPMG staff, there are challenges of using forensic accounting in the prevention and detection of fraud in projects. Meaning forensic accounting is not merely linked to the discovery of scam and fraud within a project. To the view of the author, project managers who deal fraudulently in projects would do everything possible to conceal their crimes. Staff at KPMG mentioned some of the challenges facing the forensic accounting fraternity in the avoidance and discovery of scam in projects. These are; Low patronage and Limited trained personnel. To the researcher, the lack of qualified accountants with adequate practical expertise on scientific issues is one of the major problems of forensic accounting or accounting in Ghana.

\section{Conclusion}

There will be little or no debate that fraudulent activities negatively impact projects and their stakeholders resulting in loss of huge capital. Forensic accounting, as an administrative function, is instrumental in the overall protection of project assets. Forensic accountants have a mandate to detect any potential fraud and conduct investigations of cases at hand and at least suggest effective ways of preventing the occurrence of such frauds. Forensic accounting has in stock a lot of benefits for the Projects Community in Ghana especially when forensic accountants are retained for forensic accounting purposes. It is important to note that, there's an increase in fraud and white-collar crime over the past years, and experts predict that the tendency to keep on growing if adequate measures are not taken to curb this treachery. So in the pursuit to combat fraud, the concept of forensic accounting was introduced. With forensic accounting techniques all the potential red flags within the project can be crystallized. It can also be concluded that, there are challenges using forensic accounting in the prevention and detection of fraud in projects. Because the practice of forensic accounting is not widespread in Ghana, its patronage is also low. Limited trained personnel is another great challenge facing forensic accounting firms.

The following recommendations are made; First forensic accounting is recommended to all accounting firms engaged in project management in Ghana; especially the large firms by equipping their staff with the necessary training in forensic accounting. This would help the project management firms they audit to reduce the huge sums of money they lose to fraud during projects which in return will help them concentrate on their core projects and gain a competitive advantage in the global market. It is highly recommended to all project management firms to employ the service of forensic accountants immediately there are suspects of ongoing computer crime or fraud to investigate the problem, document findings, and make recommendations. It is recommended to the government and project owners to ensure that people suspected to be corrupt and fraudsters account for their sources of wealth. It is also recommended to all project management firms to have a fraud response plan as an integral part of the firm's contingency plans. Based on review of collected data and discussions, fraud detection and prevention policies in Ghana need reviews and implementation strategies especially in the public projects. Fraud has negative impact on both individual citizens and the economy at large. 


\section{References}

[1] Bhasin, M. L., Shaikh, J. M. "Voluntary Corporate Governance Disclosures in the Annual Reports: An Empirical Study." International Journal of Managerial \& Financial Accounting. 2013; 5(1): 79-105.

[2] Jafaru, J. Forensic Accounting Practice in Nigeria: A New Paradigm for Stakeholders. 2011. Available from: http:// www.iiued.ed.press/journal/sds.

[3] Okoye, E. I., Gbegi, D. O. Forensic Accounting: A Tool for Fraud Detection and Prevention in the Public Sector (A Study of Selected Ministries in Kogi State). International Journal of Academic Research in Business and Social Science. 2013; 3(3).

[4] Oguma, S. Why We Train Our Members in Forensic Accounting. The Nigerian Accountant. 2011; $22(2): 15$.

[5] Vitez, O. Role of accounting in the modern business environment. 2015. Available from: http://smallbusiness.chron. com/role-accounting-modern-business-environment-4010.html.

[6] Drury, C. Management accounting for business. 4th ed. The United Kingdom: Cengage Learning EMEA; 2009.

[7] Dreyer, K. A History of Forensic Accounting. 2014. p.296. Available from: http://scholarworks.gvsu.edu/ honorsprojects/296/?utm_source=scholarworks.gvsu.edu\%2Fhonorsprojects\%2F296\&utm_medium=PDF\&utm_ campaign $=$ PDFCoverPages.

[8] Arokiasamy, L., Cristal-Lee. S. Forensic Accounting: Public Acceptance towards Occurrence of Fraud Detection. International Journal of Business and Management. 2009; 145-160.

[9] Ozkul, F. U., Pamukc, A. Fraud detection and Forensic Accounting. Istanbul, Turkey; 2012.

[10] Alpha Bernard Bangura. Forensic Accounting Techniques and Fraud Prevention in Sierra Leonean Deposit Money Banks. Asian Journal of Economics, Business and Accounting. 2020.

[11] Singleton, T. W. Fraud auditing and forensic accounting. John Wiley \& Sons; 2010.

[12] Silverstone, H., Sheetz, M., Pedneault, S., Rudewicz, F. Forensic accounting and fraud investigation for non-experts. Hoboken, NJ: Wiley; 2004.

[13] Ozili, P. K. Forensic Accounting and Fraud: A Review of Literature and Policy Implications. International Journal of Accounting and Economics Studies. 2015; 3(1): 63-68.

[14] Chatterji, A. N. Forensic Auditing and Investigation India. Mumbai Publishers; 2007.

[15] Ezeilo, G. Forensic Accounting. Lagos: Institute Chartered Accountants Publications; 2010.

[16] Report to the nations on occupational fraud and abuse. Association of Certified Fraud Examiners. 2012.

[17] Kessler, M. G. Forensic Accounting Services financial fraud detection. New York: Kessler International Publication; 2011.

[18] Ozili, P. K. Advances and issues in fraud research: a commentary. Journal of Financial Crime. 2020; 27(1).

[19] Liodorova, J., Fursova, V. Forensic Accounting in the World: Past and Present. Journal of Economics and Management Research. 2018; 7: 84-99. Available from: http://doi.org/10.22364/jemr.7.06.

[20] U. A. H. A. Rathnasiri, R. M. S. Bandara. The Forensic Accounting in Sri Lanka Perception of Professional Accountants. Kelaniya Journal of Management. 2018; 6(2): 68.

[21] HIGSON, A. Forensic accounting. The British Accounting Review. 2002; 34(4): 419-421. Available from: https://doi. org/10.1006/bare.2002.0212.

[22] Omane-Antwi K. Bosiako. Auditing, theory and practices. The auditing compendium. 2009.

[23] Felix I. Lessambo. Auditing, Assurance Services, and Forensics. Springer Science and Business Media LLC; 2018. 